\title{
The Ever-Elusive Endothelial Progenitor Cell: Identities, Functions and Clinical Implications
}

\author{
CHAD L. BARBER AND M. LUISA IRUELA-ARISPE \\ Molecular Biology Institute [C.L.B., M.L.I.-A.], Department of Molecular, Cellular and Developmental Biology [M.L.I.-A.], Jonsson \\ Comprehensive Cancer Center [M.L.I.-A.], University of California, Los Angeles, Los Angeles, CA, 90095
}

\begin{abstract}
The concept of an Endothelial Progenitor Cell (EPC) that participates in adult angiogenesis is less than a decade old, yet it has received a great deal of attention due to its potential for cellbased clinical therapies in many pathologies. However, controversy remains as to the identity of this bone marrow-derived cell type and its ability to give rise to new endothelium in the adult. Reports on the contribution of EPCs to new vessels in ischemic tissue or tumors vary widely, ranging from $80-90 \%$ to negligible. As researchers hone their ability to identify, isolate, and expand these cells by their markers and functionality, mounting evidence suggests that they might constitute multiple, but related cell types. At least two general phenotypes have emerged from studies of bone marrow-derived cells contributing to angiogenesis: one that incorporates into the endothelial wall directly contributing to vascular expansion and another that is able to home to neovessels, but it locates behind the endothelial wall. Nonetheless, experimental evidence indicates that this second cell type supports the viability of newly formed vessels and thus it is equally relevant to neovascular growth. As our understanding of neovascularization in pathologic states expands, a more clear definition of the multiple cellular components required for the process will shed light into new models of therapeutic intervention. The identification of a cell type that could be isolated, expanded and infused into a patient would be very useful for promoting angiogenesis in ischemia, myocardial infarct and other pathologies. (Pediatr Res 59: 26R-32R, 2006)
\end{abstract}

\section{HISTORICAL PERSPECTIVE}

$\mathrm{V}^{\mathrm{a}}$ ascular morphogenesis in the embryo is initiated by a progenitor cell of mesodermal origin, the hemangioblast, capable of giving rise to endothelial and hematopoetic lineages. In the adult, however, the presence of a common hematopoietic/endothelial progenitor has been long debated with relatively little experimental evidence. Mechanisms of postnatal angiogenesis were assumed to involve the local outgrowth of pre-existing vessels via the expansion of mature endothelial cells in response to angiogenic growth factors. However, the search for an adult "hemangioblast" was given stronger consideration when Asahara and colleagues described

Received November 16, 2005; accepted December 21, 2005.

Correspondence: M. Luisa Iruela-Arispe, Ph.D., Molecular Biology Institute, Boyer Hall, 559, 611 Charles E. Young East, Los Angeles, CA 90095; e-mail: arispe@ mbi.ucla.edu.

This work was supported by grants from the National Institutes of Health to M. Luisa Iruela-Arispe (1RO1CA77420, 2RO1CA65624, 1RO1HL074455). Chad L. Barber holds a Pre-Doctoral Fellowship from the American Heart Association (0515003Y). that a peripheral blood mononuclear population was able to differentiate into endothelial cells in vitro and incorporate into ischemic tissues at sites of angiogenesis (1). Shortly after Asahara first documented the presence of an endothelial progenitor in the circulating blood, Shi, and colleagues cultured a bone marrow-derived CD34+ subset of cells and found that these cells were able to differentiate into endothelial cells and colonize aortic Dacron implants (2). These findings indicated the existence of a bone marrow source of endothelial progenitors that could be recruited to a site of vascular repair and contribute to the expansion of the vasculature.

Additional studies reported similar phenomena demonstrating the incorporation of progenitor cells in vessels under repair in limb ischemia (3-10), sites of myocardial infarct (11-14), wound healing $(1,15-17)$, and atherosclerotic plaques $(18,19)$. Models of tumor vascularization also showed bone marrow-derived cells incorporated into tumor neovessels $(15,20-24)$. A pinnacle study, demonstrating the dependence of bone marrow-derived endothelial progenitors for tumor growth, came in 2001, when Lyden and colleagues used an angiogenesis-impaired mouse model, a double knock-out for the Id1/Id3 genes. This mouse failed to grow solid tumors due to poor vascular growth. Interestingly, tumor growth was restored after transplantation of wild type bone marrow, suggesting that neovascularization of tumors required cells from the bone marrow (21). Studies before this landmark report had indicated the potential of a bone marrowderived precursor to contribute to endothelium, but failed to document a strict requirement of this endothelial progenitor to the progression of angiogenesis. Nonetheless the complete lack of tumor growth in the absence of these progenitor cells and its restoration after transplantation provided a concrete demonstration that a bone marrow-derived cell was necessary and sufficient for adult neovascularization.

These studies engendered tremendous enthusiasm in the field. For the first time, rapid and clinically meaningful therapies could be exploited with vast implications to a multiplicity of vascular diseases. The immediate challenge faced by the

Abbreviations: CEC, circulating endothelial cell; EPC, endothelial progenitor cell; HAEC, human aortic endothelial cell; HUVEC, human umbilical vein endothelial cell; VEGF, vascular endothelial growth factor; VEGFR2, vascular endothelial growth factor receptor 2

DOI: 10.1203/01.pdr.0000203553.46471.18 
next wave of studies was the identification of this progenitor and the functional demonstration that this cell had a high potential for endothelial incorporation. These initial studies identified subsets of cells with similar potential for endothelial repair, but with widely variable levels of engraftment and, possibly, different roles in the angiogenic process. In the literature, the reported engraftment has ranged from $<1 \%$ to $95 \%(25,26)$. More recently, several studies have down-played the direct involvement of bone marrow-derived endothelial progenitors as a mechanism for the physical expansion of the endothelial wall (27-30). Rather, these results would imply that endothelial progenitor cells (EPCs) represent a monocytic-macrophage cell that aids in the repair and angiogenic potential of vessels undergoing growth via sprouting and that home to the perivascular space. Together, the recent findings do not directly contest the conclusions obtained by Lyden, but question the mechanism by which bone marrow-derived cells are participating in vascular expansion and to what degree. This point has not been resolved and is the subject of much discussion.

The cell surface markers, experimental models, and engraftment readout in the aforementioned studies have varied significantly, leading to controversy as to the identity of an EPC and its role in adult angiogenesis (Table 1). Regardless, cell based therapies are currently being explored in pilot clinical studies. Thus, an overriding theme is the need to establish a working definition for the EPC. The current definition includes a cell that: 1) resides in the bone marrow and can be recruited by mobilizing growth factors or other cues to sites of vascular injury or tumor growth; 2) expresses surface markers that include both endothelial and hematopoetic cell types; 3 ) can be distinguished from mature, differentiated circulating endothelial cells (CECs); and 4) can integrate into the endothelium at sites of vessel repair or angiogenesis $(33,40)$ (Fig. 1). This definition, however, in light of the above conflicting reports, remains ever changing and incomplete. The identification of all bone marrow-derived cells involved is paramount to define their specific contributions to growing vessels. In this review we provide a summary and discussion of the limitations encountered by investigators in this area, the novel approaches being used to reconcile conflicting reports, and the current functional view of endothelial cell progenitors.

\section{THE DIFFICULTIES IN IDENTIFYING EPCS: TOOLS, MARKERS AND MODELS}

Indispensable tool: Flow cytometry. Flow cytometry has proven an indispensable tool in studying endothelial progenitors. Cell surface markers that represent cell populations with both hematopoietic and endothelial lineages can be detected, quantified and isolated for further exploration in functional assays $(31,32)$. The method is extremely sensitive and it provides the easiest alternative for screening large numbers of cells, quickly and accurately, using multiple parameters (markers) needed to identify rare progenitor populations. EPCs have been shown to represent between $0.01 \%$ and $0.0001 \%$ of the total mononuclear cell fraction from a normal peripheral blood sample, making collection efforts dependent on a very large amount of blood or pooling of multiple samples (32). A widely used method of enriching the EPC fraction in blood is to use known mobilization factors as a

Table 1. Summary of in vivo studies on EPCs, markers, and results

\begin{tabular}{|c|c|c|c|c|}
\hline Source of cells & Surface marker/model & Functional readout & Percent incorporation & Reference \\
\hline $\begin{array}{l}\text { PB-MNC (mouse and } \\
\text { rabbit) }\end{array}$ & $\mathrm{CD} 34 / \mathrm{flk} 1, \mathrm{CD} 45$ & Hind limb ischemia & $\begin{array}{l}13.4 \pm 5.7 \% \text { (mouse) or } 9.7 \pm 4.5 \% \\
\quad \text { (rabbit) }\end{array}$ & 1 \\
\hline Canine BM-MNC & CD34, vWF, DiI-Ac-LDL & Incorp. Into Dacron graft & ND & 2 \\
\hline Human PB-MNC & CD34, Tie2, DiI-Ac-LDL & Hind limb ischemia & High, not quantified & 7 \\
\hline Mouse BM-MNC & Tie2/LacZVEGFR2/LacZ & $\begin{array}{l}\text { Colon cancer, Inductive } \\
\text { ovulation, wound healing, } \\
\text { ischemia }\end{array}$ & Diffuse, not quantified & 13 \\
\hline Human PB-MNC & $\begin{array}{l}\text { VEGFR2, Tie2, CD133, } \\
\text { GATA-2, c-kit }\end{array}$ & Myocardial reperfusion & $20-25 \%$ & 14 \\
\hline Mouse BM-MNC & SCL-1/LacZ & Tumor xenograft & $0 \%$ & 26 \\
\hline Mouse BM-MNC & Tie2/LacZ & Soft tissue graded ischemia & $\begin{array}{l}\text { Correlates to level of } \\
\text { ischemia, not quantified }\end{array}$ & 49 \\
\hline Human BM-MNC & CD31, vWF, Y chromosome & $\begin{array}{l}\text { Human sex-mismatched } \\
\text { BMT }\end{array}$ & $2 \%$ & 59 \\
\hline \multicolumn{5}{|c|}{$\begin{array}{l}\text { Cells cultured/manipulated } \\
\text { in vitro before assay }\end{array}$} \\
\hline Human PB-MNC & $\begin{array}{l}\text { CD14, Endoglin, Dil-Ac-LDL, } \\
\text { vWF, CD45, VEGFR2, }\end{array}$ & Hind limb ischemia & $19.8 \pm 8 \%$ & 10 \\
\hline Mouse BM-MNC & VEGFR1, VEGFR2, & Tumor xenograft & $55-95 \%$ & 19 \\
\hline Human BM-MNC & $\begin{array}{l}\text { CD34-, VE-Cad-, VEGFR2+, } \\
\text { AC133+ }\end{array}$ & $\begin{array}{l}\text { Tumor xenograft/wound } \\
\text { healing }\end{array}$ & $35 \% / 30-45 \%$ & 20 \\
\hline $\operatorname{Lin}(-) \mathrm{BM}-\mathrm{MNC}$ & LentiviralTie2-GFP & Tumor xenograft & $<1 \%$ & 25 \\
\hline Mouse BM-MNC & Tie2/GFP & Tumor xenograft & EC: $1-2 \%$ Monocyte: $4 \%$ & 28 \\
\hline HUVEC/HAEC & Unselected & Murine Tumor xenograft & Not quantified & 68 \\
\hline Sheep PB-MNC & $\begin{array}{l}\text { VEGFR2, Tie2, vWF, CD31, } \\
\text { Dil-Ac-LDL }\end{array}$ & Vessel graft survival & $80 \%$ & 69 \\
\hline
\end{tabular}

PB-MNC, Peripheral Blood-Mononuclear Cell; BM-MNC, Bone Marrow-Mononuclear Cell; ND, not determined; HSC, Hematopoetic Stem Cell; HUVEC, human umbilical vein endothelial cell; HAEC, human aortic endothelial cell; BMT, bone marrow transplantation; lin(-), lineage negative. 


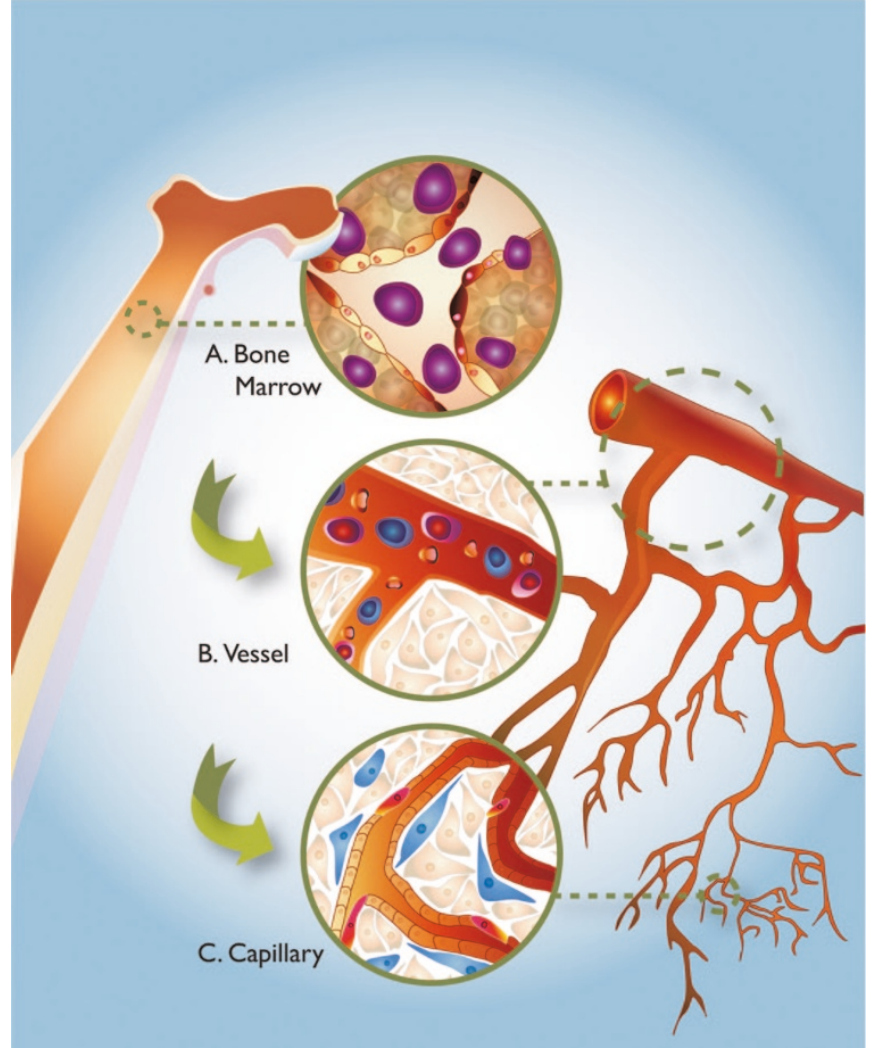

Figure 1. EPCs are bone marrow-derived cells that contribute to postnatal angiogenesis. EPCs (seen in purple at $A$ ) can be mobilized from the bone marrow stroma by various growth factors and exit through sinusoidal vessels. Once in the bloodstream $(B)$, EPCs begin to differentiate (indicated by the color change). Subsequently, these cells home to sites of angiogenesis in capillary beds $(C)$ and attach to the endothelium. Unknown mechanisms drive endothelial precursors (red) to incorporate into the endothelial wall or proangiogenic monocytes (blue) to locate behind the endothelial wall and support the stability and viability of the local endothelium by paracrine mechanisms.

treatment to artificially recruit cells into circulation. Vascular Endothelial Growth Factor (VEGF), Stromal Derived Factor-1 (SDF-1), Granulocyte-Colony Stimulating Factor (G-CSF), Granulocyte/Macrophage- Colony Stimulating Factor (GMCSF), and Angiopoietin 1 (Ang-1) are a few of the most used factors that can mobilize EPCs, that is, these factors have been shown to recruit EPCs from the bone marrow into the circulation $(5,6,21,33,34)$.

The biology behind how these factors mobilize EPCs from the marrow is not entirely understood. However, it appears that matrix metalloproteases are involved in at least one step. Matrix Metalloprotease 9 (MMP-9), an extracellular matrix metalloproteinase expressed by bone marrow stromal cells, is required for shedding c-kit (a cell surface molecule expressed by stem/progenitor cells) from the cell surface; this event appears to be an essential signal for EPC release from the marrow stroma. Likely, multiple mechanisms participate in the exit of EPCs from the marrow; some of these are likely to be dependent on the stimulus (VEGF versus SDF-1, for example). Regardless of the specific mechanism, the release of EPCs from the bone marrow upon exposure to these factors is well documented and is an established technique for increasing the yield of these cells experimentally.
With recent advances in cytometric technology, the explosion of available MAb, and increased knowledge in stem and progenitor cell biology, flow cytometry has become the gold standard for characterization and isolation. However, it has limitations in the context of studying differentiating cells, as the cell surface molecules used as markers represent only a snapshot of a highly plastic and immature cell type. Presumably, the EPC exists in multiple states of differentiation in any peripheral blood sample. A putative EPC is likely to display a complement of surface markers when in the bone marrow that changes once released into blood stream and subsequently within the growing vessel at its final destination. Unfortunately, flow cytometry also fails to reveal the source of the cell if not used in combination with a technique to indicate bone marrow origin. For example, mature CECs have been shown to slough off from the endothelial wall, circulate and can be mistaken for circulating EPCs originating from the bone marrow $(25,26,32,35,36)$. To overcome these concerns many studies currently use flow cytometry in combination with functional assays and these have supported a significant, yet incompletely understood, role for a bone marrow-derived cell in vascular repair and neoangiogenesis.

Cell surface markers. Flow cytometry relies on the specificity of cell surface proteins expressed by distinct cell populations and the corresponding antibodies that are used to identify them. The most widely used combination of surface markers for identifying peripheral blood EPCs have been CD34, Prominin-1 (CD133) and VEGFR2/flk-1 (4,26,37). Certain considerations exist in using these markers mostly because alone, none are specific for EPCs. CD34, for example, is a hematopoietic marker and can be found on other bone marrow-derived stem cells. In fact, EPCs represent a very small fraction of the total CD34+ population in the bone marrow or peripheral blood (32). CD34 can also be found on mature CECs (38). Therefore, CD34 must be used in conjunction with other markers to identify a more specific population of cells. A list of common markers used for EPC identification, alternate names and expression on cell types other than EPCs can be found in Table 2.

CD133 was first isolated and characterized by Weigmann, as a marker of neuroepithelial stem cells (39). It was subsequently noted by a second group to be expressed on CD34+

Table 2. Common surface markers used in EPC identification

\begin{tabular}{|c|c|c|}
\hline Marker & Alternate names & Expression on cells other than EPCs \\
\hline CD34 & Mucosialin & Capillary endothelial, HSCs \\
\hline CD133 & Prominin-1 & $\begin{array}{l}\text { Neuroepithelial, kidney epithelium, } \\
\text { cancer cells }\end{array}$ \\
\hline c-kit & CD117 & HSCs, germ cells, mast cells \\
\hline Sca-1 & Ly6A/E & $\begin{array}{l}\text { HSCs, granulocytes, monocytes, B cells, } \\
\text { T subset and activated T-cells }\end{array}$ \\
\hline Tie2 & TEK, CD202b & HSCs, CECs, adult: unknown \\
\hline VEGFR2 & $\begin{array}{l}\text { KDR (human) or } \\
\text { Flk1 (mouse) }\end{array}$ & CECs \\
\hline vWF & Factor XIIIvWF & CECs \\
\hline $\mathrm{CD} 31$ & PECAM-1 & $\begin{array}{l}\text { Platelets, granulocytes, dendritic cells, } \\
\text { monocytes, T subsets, B subsets }\end{array}$ \\
\hline Endoglin & CD105 & Activated Macrophage \\
\hline CD45 & LCA, Ly5 & Pan-leukocyte \\
\hline
\end{tabular}


hematopoetic stem cells $(40,41)$. Since, CD133 has held great promise for being a definitive EPC marker because of its seemingly specific expression pattern in endothelial progenitors in the adult. This was in spite of some embryonic, nonendothelial tissue expression that was detected when first cloned and characterized $(38,41-43)$. As the endothelial progenitor differentiates into a mature endothelial cell, CD133 is down-regulated, presumably while cells are in transit and in the process of differentiating into mature endothelial cells. At this point, the expression profile of EPCs has been shown to change and acquire markers such as von Willebrand Factor (vWF), Platelet Endothelial Cell Adhesion Molecule-1 (PECAM-1 (CD31)) and Vascular Endothelial-Cadherin (VECad) (44). Consistent with this notion, cultured CD133+ cells differentiate into mature endothelial cells as demonstrated by expression of specific markers (23). Reports of CD133 expression in a bone marrow-endothelial progenitor gave weight to the notion that CD133 was a definitive marker for the EPC.

Unfortunately, subsequent studies demonstrated promiscuous expression in adult epithelial cell types, as well as other nonendothelial immature cell types in the adult (45). More recent clinical studies on patients with nonsmall cell lung carcinoma (NSCLC) have argued against the notion that CD133 is an endothelial progenitor marker (46). Florek and colleagues used a CD133 specific antiserum as opposed to a $\mathrm{MAb}$ to study the adult expression pattern and found expression in the adult kidney and mammary gland (45). They also found expression at the periphery of kidney tumors. This observation along with several others noting expression in solid tumors and in several leukemias, gave rise to the additional classification of CD133 as a cancer stem cell marker. It should be stated that the function of CD133 is yet to be determined (42). This engenders some uncertainty about using it as a definitive endothelial progenitor marker, at least until its role in endothelial progenitor function can be established.

Lastly, the marker VEGFR2 is expressed by mature endothelial cells and is often used to delineate EPC populations in bone marrow or peripheral blood cells. CECs, being endothelial cells sloughed from a vessel wall, also express VEGFR2, possibly mistaking differentiated cells of non-bone marrow origin for EPCs. Thus, stem cell markers are used in combination with VEGFR2 to ensure the progenitor nature of the cell (38). Additional cell surface markers that have been used to identify cells with progenitor characteristics are c-kit and Sca-1. The role of c-kit in EPC biology was discussed above and it relates to their mobilization from the bone marrow. Sca-1 appears to be associated with cell fate decisions of pluripotent progenitors and regulation of c-kit expression. In fact, Sca-1(-/-) bone marrow cells had fewer myeloid progeny and decreased c-kit on their cell surface (47). Again, when used in combination, these markers may detect more defined populations of a possible EPC, but may still exclude important intermediaries or include side populations that do not directly contribute to angiogenesis. With the limitations of cell surface marker characterization, genetic techniques have been used to more accurately trace cell lineages of interest.

Genetic models. With no clear understanding of the contextual clues for differentiation during the transit of EPCs and the incomplete characterization of their cell surface markers, it is difficult to pin-down the exact phenotype of the EPC population in human samples or in experimental models. Therefore, genetic markers have been used in combination with bone marrow transplantation models to trace cells of bone marrow origin to their end point in sites of angiogenesis. Whereas cell surface markers may be transiently expressed, a genetic marker is a permanent event regardless of the differentiation status of that cell.

In some instances, Cre-recombinase in combination with a reporter gene preceded by a loxP-stop codon-loxP cassette has been used to trace that cell and mark its entire progeny. Current genetic models that have allowed significant insight into EPC biology include Tie2/LacZ and Tie2/GFP, SCL-1/ LacZ, and VE-Cadherin/Cre/Rosa26R.

Tie-2 is a receptor tyrosine kinase expressed by endothelial and some hematopoietic cells. The promoter has been effective for tracking endothelial progenitors in neovessels in tandem with bone marrow transplantation studies $(15,48-50)$. The ligand for Tie2 receptor is Angiopoietin-1, and as aforementioned, Ang- 1 can be used to artificially mobilize EPCs and enrich the peripheral blood with Tie2 expressing cells. The Tie2 model has been extremely useful in tracking cells thought to be involved in postnatal angiogenesis, however, the normal expression pattern of Tie 2 in the adult vasculature remains largely uncharacterized, an unfortunate caveat for some studies.

Evaluation of EPCs in tumor angiogenesis (15) and ischemia, (15,50,51), using Tie2 expressing bone marrow cells, have shown endothelial incorporation and differentiation. However, there have been other reports of a Tie2 expressing monocytic cell type homing to the perivascular space that does not contribute directly to the endothelial wall $(27,30,52,53)$. Interestingly, elimination of this monocytic cell type resulted in a significant inhibition of tumor growth in mouse xenograft assays. This finding, in combination with similar studies, plainly demonstrates the contribution of multiple cell types in tumor angiogenesis. Recently, De Palma and colleagues characterized three distinct cell types that were targeted by a Tie2 lentiviral vector (30). Therefore, evaluation of models using Tie2 as a genetic marker may be difficult to compare with other EPC studies, as the subset of cells being evaluated might not be entirely specific to the endothelial lineage.

A transgenic mouse using an enhancer element from the stem cell leukemia-1 (SCL-1) gene has also been used in EPC lineage studies (54). This transcription factor was identified in hematopoietic disorders, as mutations were noted in several types of leukemia. Nonetheless, SCL was also found to be expressed by endothelial cells during development $(54,55)$. Further dissection of the SCL promoter using transgenic mice identified a $5^{\prime}$ element shown to drive expression specifically in the endothelial compartment. By using a tamoxifen-inducible reporter system driven by the SCL-1 endothelial enhancer, Gothert and colleagues found that newly generated vessels did not contain any bone marrow-derived cells, but rather were derived from the hosts' mature endothelial cells (28). This is in contrast to other genetic models, including those using VE-Cadherin.

VE-Cadherin (or CD144) is an endothelial specific adhesion molecule that binds homotypically to molecules on adjacent 


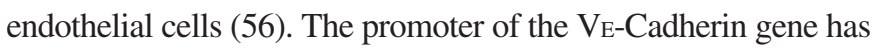
been well characterized and its activity appears to be constitutive in all endothelial cells during development, as well as in the adult quiescent endothelium (57-59). Because of its broad and constitutive endothelial expression, a transgenic model was developed in which the VE-Cadherin promoter drives expression of CreRecombinase (60). Once mated with the ROSA26R mouse, the resulting combination provides a functional read-out of the Cre activity via the expression of the lacZ reporter gene (61). Being an irreversible excision, LacZ serves as permanent marker for all VE-Cadherin expressing cells and their progeny, irrespective of

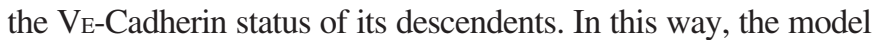
offers a lineage map of cells that at one time had expressed

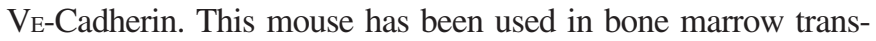
plantation studies and revealed low, albeit clear contribution of bone marrow cells to the endothelial wall of tumor neovessels. It has also shown monocytic cells within the perivascular space of the tumor, a result of VE-cadherin expression in hematopoietic progenitors. The finding of monocytic cells is also consistent with reports by several other groups using different models $(27,30,52)$.

Retrospective human studies. Perhaps one of the greatest untapped resources for evaluation of EPC incorporation is preserved human tissue obtained from biopsies posttransplantation. One of the most convincing studies used patients that underwent sex-mismatched bone marrow transplants. Searching for the $\mathrm{Y}$ chromosome in tissue from female recipients, it was possible to demonstrate bone marrowderived cell incorporation in the endothelium. The study reports that on average $2 \%$ of the recipients' endothelium was donor-derived (62). Human atherosclerotic plaques from sexmismatched recipients have also been evaluated and shown to contribute to smooth muscle cells associated with the vessel along sites of plaque formation (63). In cases of heart transplantation and coronary artery grafts, host cells were found contributing to the grafted tissues' endothelium (64). Transplanted liver patients also displayed significant contribution to the new organs' endothelium (65).

In vitro expansion of progenitor populations. EPCs are a rare population in the peripheral blood and bone marrow. As aforementioned, they represent between $0.01 \%$ and $0.0001 \%$ of the total peripheral blood mononuclear cell (PB-MNC) fraction from a normal blood sample. For this reason, researchers have cultured subsets of cells taken from total PBMNCs in vitro in an effort to obtain a sufficient number of cells to test incorporation or vascular repair in vivo. Many studies are also employing in vitro culture to produce a large number of relatively clonogenic endothelial precursors (66).

The success of ex vivo amplification and/or genetic manipulation in many reports has already yielded promise for clinical use $(24,27,30,67-70)$. Many studies currently rely on in vitro growth behavior as a selection criteria for EPCs (71). However, there is an inherent risk in driving the cells' differentiation program by changing its microenvironment. Removing EPCs from the contextual clues present in the bone marrow stroma or peripheral blood, or by addition of artificial signals, is likely to induce differentiation toward a particular phenotype and force highly plastic cell types to assume a precursor identity that might not normally occur in vivo.
In considering data from transplantation or infusion studies using ex vivo expanded cells there is, on average, a higher reported incorporation rate than in experiments using noncultured cells, (about 7\%, as opposed to 2\%) (25). This increased incorporation may be due to a re-programming event, whereby culture conditions elicit a differentiation response from multiple progenitor cell lineages toward the endothelial fate that might not occur in all cells in vivo. Koizumi and colleagues have assessed the incorporation rate of organ derived endothelial cells, such as human aortic endothelial cells (HAEC) and human umbilical vein endothelial cells (HUVEC) and found both, seemingly mature, endothelial cell types to possess the potential to survive, proliferate and incorporate, when transplanted, into mouse endothelium (72). Recently, longterm culture experiments were performed with HAEC and HUVEC cells (73). These cells were previously thought to be short-lived in culture because of their differentiated state. However, these cells proliferated in vitro just as long as EPC cultures from other experiments. Also, a small percentage of cells in HUVEC and HAEC cultures had progenitor characteristics, similar to those of EPCs (73). This paradox led to the conclusion that there might be tissue-resident EPCs (71).

With respect to clinical applications for cell-based therapy in revascularization, the real or induced potential of a progenitor bears little importance as long as there is measurable improvement in the patients' condition. In fact, driving differentiating cells down an endothelial path may be useful in the repair of injured endothelium. However, for the future of EPC therapy, clarifying the contribution and identity of all involved cell types will aid in reducing side effects and enhancing desired outcomes.

\section{THE PRO-ANGIOGENIC MONOCYTE: AN INSTRUCTIVE EPC?}

As mentioned above, several cell types that differ slightly in molecular cell surface repertoire of proteins have been identified. More importantly, these cell types have displayed functional differences with regard to their effects in vivo. It was assumed that the most obvious role for an endothelial progenitor would be its direct contribution to the endothelial wall. However, two phenotypes have emerged from the data regarding the differentiation fate of the EPC. One, as mentioned above, integrating into endothelium, and another that takes residence immediately behind the vessel wall $(52,74-76)$. The role of this second cell type is presumably to provide paracrine signals to nearby endothelial cells (Fig. 1). In fact, this "proangiogenic monocyte" has been found to secrete angiogenic growth factors to the adjacent endothelial cells. Rehman and colleagues cultured peripheral blood mononuclear cells and found that they secreted high levels of VEGF, HGF, G-CSF and GM-CSF (52). It has become apparent that mural cells, which consist of pericytes and vascular smooth muscle cells, are critical mediators in the angiogenic response and directly contribute to vascular stability and remodeling. In a recent study, Tie2 expressing monocytic cells were co-injected with tumor cells. In that study, it was found that there was a significant increase in the level and quality of angiogenesis compared with injecting tumor cells alone (30). Numerous 
studies have reinforced the importance of interaction between the vascular endothelium and mural cells (reviewed by Armulik, 2005) (77). Therefore, it is conceivable that a marrow-derived cell could aid in the establishment of new capillary beds by providing important paracrine signals and not by contributing directly to the endothelial wall. The pro-angiogenic monocyte would then, by the current definition, not be an EPC. These observations present a paradigm shift from the simplistic view that a single cell type is responsible for angiogenic growth in adult tissues and steers toward a process where multiple bone marrow-derived cells are involved.

\section{FUTURE DIRECTIONS}

The potential therapeutic value of EPCs is undisputed. What remains in dispute, however, is the definition of the EPC. The specific questions that will help to define the EPC are: Which are the pro-angiogenic progenitors in the bone marrow? What is the identity (cell surface repertoire) of the EPC while in circulation? What are its roles in angiogenesis? By striving to more accurately characterize, the cells involved in the process of postnatal angiogenesis, by both phenotype and function, researchers will be able to better compare their results and select subsets of cells with advantageous characteristics for use in future clinical trials.

At least two independent bone marrow-derived cell types have now been described and implicated in vascular expansion/viability using various techniques. One has been shown to differentiate into a mature endothelial cell and directly incorporates into the endothelial wall. The other appears to have monocytic features, incorporates behind the endothelial wall, and secretes pro-angiogenic growth factors, presumably to enhance the survival and growth of the nearby resident endothelial cells. Rather than juxtaposing these data, some investigators viewed this as quite fortuitous, as multiple subsets of cells could modulate angiogenesis by independent mechanisms that could be exploited in the development of strategies for therapy. Clinical trials with subsets of bone marrow cells are progressing with extreme caution, with the understanding that inclusion of side population cells that might not contribute to angiogenesis could be harmful. The most appealing explanation for the diversity of observations of EPC function is a highly plastic cell type with the ability to respond to the vascular needs of the immediate surroundings once it has been recruited to the site of angiogenesis.

Due to their accessibility and rapid response, circulating EPCs have been used as surrogate markers for a wide variety of pathologies. Several experimental studies have shown a direct correlation between EPCs and pathologic status. In fact, these cells have been shown to correlate with ischemia extent in a stroke or myocardial infarction; level of angiogenesis in tumors; and risk factor status in interventions associated with atherosclerosis. While the use of EPCs as surrogate markers in the clinic might occur soon; a more direct exploration of these cells as therapeutic tools in patients is long-reached. Additional information from basic science is needed to aid in the development of safe and predictable therapies with measurable outcomes.

There is little doubt that adult angiogenesis is a more complex process than previously anticipated. Nonetheless, persistent exploration of the biology of EPCs in preclinical settings will most likely allow a quick transition of this technology into clinically relevant therapies.

Acknowledgments. We would like to thank Amanda Hammond for her artistic rendering in Fig. 1 and Dr. Sunyoung Lee and Dr. Minako Partyka for critical evaluation of the review.

\section{REFERENCES}

1. Asahara T, Murohara T, Sullivan A, Silver M, van der Zee R, Li T, Witzenbichler B, Schatteman G, Isner JM 1997 Isolation of putative progenitor endothelial cells for angiogenesis. Science 275:964-967

2. Shi Q, Rafii S, Wu MH, Wijelath ES, Yu C, Ishida A, Fujita Y, Kothari S, Mohle R, Sauvage LR, Moore MA, Storb RF, Hammond WP 1998 Evidence for circulating bone marrow-derived endothelial cells. Blood 92:362-367

3. Asahara T, Kalka C, Isner JM 2000 Stem cell therapy and gene transfer for regeneration. Gene Ther. 7:451-457

4. Asahara T, Isner JM 2002 Endothelial progenitor cells for vascular regeneration. J Hematother Stem Cell Res 11:171-178

5. Takahashi T, Kalka C, Masuda H, Chen D, Silver M, Kearney M, Magner M, Isner JM, Asahara T 1999 Ischemia- and cytokine-induced mobilization of bone marrowderived endothelial progenitor cells for neovascularization. Nat Med 5:434-438

6. Kalka C, Masuda H, Takahashi T, Gordon R, Tepper O, Gravereaux E, Pieczek A, Iwaguro H, Hayashi SI, Isner JM, Asahara T 2000 Vascular endothelial growth factor(165) gene transfer augments circulating endothelial progenitor cells in human subjects. Circ Res 86:1198-1202

7. Schatteman GC, Hanlon HD, Jiao C, Dodds SG, Christy BA 2000 Blood-derived angioblasts accelerate blood-flow restoration in diabetic mice. J Clin Invest 106:571-578

8. Iwaguro H, Yamaguchi J, Kalka C, Murasawa S, Masuda H, Hayashi S, Silver M, Li T, Isner JM, Asahara T 2002 Endothelial progenitor cell vascular endothelial growth factor gene transfer for vascular regeneration. Circulation 105:732-738

9. Yamaguchi J, Kusano KF, Masuo O, Kawamoto A, Silver M, Murasawa S, Bosch-Marce M, Masuda H, Losordo DW, Isner JM, Asahara T 2003 Stromal cell-derived factor-1 effects on ex vivo expanded endothelial progenitor cell recruitment for ischemic neovascularization. Circulation 107:1322-1328

10. Urbich C, Heeschen C, Aicher A, Dernbach E, Zeiher AM, Dimmeler S 2003 Relevance of monocytic features for neovascularization capacity of circulating endothelial progenitor cells. Circulation 108:2511-2516

11. Orlic D, Kajstura J, Chimenti S, Limana F, Jakoniuk I, Quaini F, Nadal-Ginard B, Bodine DM, Leri A, Anversa P 2001 Mobilized bone marrow cells repair the infarcted heart, improving function and survival. Proc Natl Acad Sci U S A 98:10344-10349

12. Orlic D, Kajstura J, Chimenti S, Bodine DM, Leri A, Anversa P 2001 Transplanted adult bone marrow cells repair myocardial infarcts in mice. Ann N Y Acad Sci 938:221-229; discussion 229-230

13. Jackson KA, Majka SM, Wang H, Pocius J, Hartley CJ, Majesky MW, Entman ML, Michael LH, Hirschi KK, Goodell MA 2001 Regeneration of ischemic cardiac muscle and vascular endothelium by adult stem cells. J Clin Invest 107:1395-1402

14. Kocher AA, Schuster MD, Szabolcs MJ, Takuma S, Burkhoff D, Wang J, Homma S, Edwards NM, Itescu S 2001 Neovascularization of ischemic myocardium by human bone-marrow-derived angioblasts prevents cardiomyocyte apoptosis, reduces remodeling and improves cardiac function. Nat Med 7:430-436

15. Asahara T, Masuda H, Takahashi T, Kalka C, Pastore C, Silver M, Kearne M, Magner M, Isner JM 1999 Bone marrow origin of endothelial progenitor cells responsible for postnatal vasculogenesis in physiological and pathological neovascularization. Circ Res 85:221-228

16. Asahara T, Takahashi T, Masuda H, Kalka C, Chen D, Iwaguro H, Inai Y, Silver M, Isner JM 1999 VEGF contributes to postnatal neovascularization by mobilizing bone marrow-derived endothelial progenitor cells. EMBO J 18:3964-3972

17. Crosby JR, Kaminski WE, Schatteman G, Martin PJ, Raines EW, Seifert RA, Bowen-Pope DF 2000 Endothelial cells of hematopoietic origin make a significant contribution to adult blood vessel formation. Circ Res 87:728-730

18. Sata M, Saiura A, Kunisato A, Tojo A, Okada S, Tokuhisa T, Hirai H, Makuuchi M, Hirata Y, Nagai R 2002 Hematopoietic stem cells differentiate into vascular cells that participate in the pathogenesis of atherosclerosis. Nat Med 8:403-409

19. Luttun A, Tjwa M, Moons L, Wu Y, Angelillo-Scherrer A, Liao F, Nagy JA, Hooper A, Priller J, De Klerck B, Compernolle V, Daci E, Bohlen P, Dewerchin M, Herbert JM, Fava R, Matthys P, Carmeliet G, Collen D, Dvorak HF, Hicklin DJ, Carmeliet P 2002 Revascularization of ischemic tissues by PlGF treatment, and inhibition of tumor angiogenesis, arthritis and atherosclerosis by anti-Flt1. Nat Med 8:831-840

20. Garcia-Barros M, Paris F, Cordon-Cardo C, Lyden D, Rafii S, Haimovitz-Friedman A, Fuks Z, Kolesnick R 2003 Tumor response to radiotherapy regulated by endothelial cell apoptosis. Science 300:1155-1159

21. Lyden D, Hattori K, Dias S, Costa C, Blaikie P, Butros L, Chadburn A, Heissig B, Marks W, Witte L, Wu Y, Hicklin D, Zhu Z, Hackett NR, Crystal RG, Moore MA, Hajjar KA, Manova K, Benezra R, Rafii S 2001 Impaired recruitment of bonemarrow-derived endothelial and hematopoietic precursor cells blocks tumor angiogenesis and growth. Nat Med 7:1194-1201

22. Reyes M, Dudek A, Jahagirdar B, Koodie L, Marker PH, Verfaillie CM 2002 Origin of endothelial progenitors in human postnatal bone marrow. J Clin Invest 109:337346 
23. Gehling UM, Ergun S, Schumacher U, Wagener C, Pantel K, Otte M, Schuch G, Schafhausen P, Mende T, Kilic N, Kluge K, Schafer B, Hossfeld DK, Fiedler W 2000 In vitro differentiation of endothelial cells from AC133-positive progenitor cells. Blood 95:3106-3112

24. Davidoff AM, Ng CY, Brown P, Leary MA, Spurbeck WW, Zhou J, Horwitz E, Vanin EF, Nienhuis AW 2001 Bone marrow-derived cells contribute to tumor neovasculature and, when modified to express an angiogenesis inhibitor, can restrict tumor growth in mice. Clin Cancer Res 7:2870-2879

25. Urbich C, Dimmeler S 2004 Endothelial progenitor cells: characterization and role in vascular biology. Circ Res 95:343-353

26. Rafii S, Lyden D, Benezra R, Hattori K, Heissig B 2002 Vascular and haematopoietic stem cells: novel targets for anti-angiogenesis therapy? Nat Rev Cancer 2:826835

27. De Palma M, Venneri MA, Roca C, Naldini L 2003 Targeting exogenous genes to tumor angiogenesis by transplantation of genetically modified hematopoietic stem cells. Nat Med 9:789-795

28. Gothert JR, Gustin SE, van Eekelen JA, Schmidt U, Hall MA, Jane SM, Green AR, Gottgens B, Izon DJ, Begley CG 2004 Genetically tagging endothelial cells in vivo: bone marrow-derived cells do not contribute to tumor endothelium. Blood 104:1769-1777

29. Jain RK, Duda DG 2003 Role of bone marrow-derived cells in tumor angiogenesis and treatment. Cancer Cell 3:515-516

30. De Palma M, Venneri MA, Galli R, Sergi LS, Politi LS, Sampaolesi M, Naldini L 2005 Tie 2 identifies a hematopoietic lineage of proangiogenic monocytes required for tumor vessel formation and a mesenchymal population of pericyte progenitors. Cancer Cell 8:211-226

31. Masuda H, Kalka C, Asahara T 2000 Endothelial progenitor cells for regeneration. Hum Cell 13:153-160

32. Khan SS, Solomon MA, McCoy JP 2005 Detection of circulating endothelial cells and endothelial progenitor cells by flow cytometry. Cytometry B Clin Cytom 64:1-8

33. Aicher A, Zeiher AM, Dimmeler S 2005 Mobilizing endothelial progenitor cells. Hypertension 45:321-325

34. Hattori K, Dias S, Heissig B, Hackett NR, Lyden D, Tateno M, Hicklin DJ, Zhu Z, Witte L, Crystal RG, Moore MA, Rafii S 2001 Vascular endothelial growth factor and angiopoietin-1 stimulate postnatal hematopoiesis by recruitment of vasculogenic and hematopoietic stem cells. J Exp Med 193:1005-1014

35. Khakoo AY, Finkel T 2005 Endothelial progenitor cells. Annu Rev Med 56:79-101

36. Lin Y, Weisdorf DJ, Solovey A, Hebbel RP 2000 Origins of circulating endothelial cells and endothelial outgrowth from blood. J Clin Invest 105:71-77

37. Hristov M, Erl W, Weber PC 2003 Endothelial progenitor cells: isolation and characterization. Trends Cardiovasc Med 13:201-206

38. Peichev M, Naiyer AJ, Pereira D, Zhu Z, Lane WJ, Williams M, Oz MC, Hicklin DJ, Witte L, Moore MA, Rafii S 2000 Expression of VEGFR-2 and AC133 by circulating human $\mathrm{CD} 34(+)$ cells identifies a population of functional endothelial precursors. Blood 95:952-958

39. Weigmann A, Corbeil D, Hellwig A, Huttner WB 1997 Prominin, a novel microvillispecific polytopic membrane protein of the apical surface of epithelial cells, is targeted to plasmalemmal protrusions of non-epithelial cells. Proc Natl Acad Sci U S A 94:12425-12430

40. Yin AH, Miraglia S, Zanjani ED, Almeida-Porada G, Ogawa M, Leary AG, Olweus J, Kearney J, Buck DW 1997 AC133, a novel marker for human hematopoietic stem and progenitor cells. Blood 90:5002-5012

41. Miraglia S, Godfrey W, Yin AH, Atkins K, Warnke R, Holden JT, Bray RA, Waller EK, Buck DW 1997 A novel five-transmembrane hematopoietic stem cell antigen: isolation, characterization, and molecular cloning. Blood 90:5013-5021

42. Shmelkov SV, St Clair R, Lyden D, Rafii S 2005 AC133/CD133/Prominin-1. Int J Biochem Cell Biol 37:715-719

43. Handgretinger R, Gordon PR, Leimig T, Chen X, Buhring HJ, Niethammer D, Kuci S 2003 Biology and plasticity of CD133+ hematopoietic stem cells. Ann N Y Acad Sci 996:141-151

44. Rafii S, Lyden D 2003 Therapeutic stem and progenitor cell transplantation for organ vascularization and regeneration. Nat Med 9:702-712

45. Florek M, Haase M, Marzesco AM, Freund D, Ehninger G, Huttner WB, Corbeil D 2005 Prominin-1/CD133, a neural and hematopoietic stem cell marker, is expressed in adult human differentiated cells and certain types of kidney cancer. Cell Tissue Res 319:15-26

46. Hilbe W, Dirnhofer S, Oberwasserlechner F, Schmid T, Gunsilius E, Hilbe G, Woll E, Kahler CM 2004 CD133 positive endothelial progenitor cells contribute to the tumour vasculature in non-small cell lung cancer. J Clin Pathol 57:965-969

47. Bradfute SB, Graubert TA, Goodell MA 2005 Roles of Sca-1 in hematopoietic stem/progenitor cell function. Exp Hematol 33:836-843

48. De Palma M, Naldini L 2002 Transduction of a gene expression cassette using advanced generation lentiviral vectors. Methods Enzymol 346:514-529

49. Asahara T, Chen D, Takahashi T, Fujikawa K, Kearney M, Magner M, Yancopoulos GD, Isner JM 1998 Tie2 receptor ligands, angiopoietin-1 and angiopoietin-2, modulate VEGF-induced postnatal neovascularization. Circ Res 83:233-240

50. Zhang ZG, Zhang L, Jiang Q, Chopp M 2002 Bone marrow-derived endothelial progenitor cells participate in cerebral neovascularization after focal cerebral ischemia in the adult mouse. Circ Res 90:284-288

51. Tepper OM, Capla JM, Galiano RD, Ceradini DJ, Callaghan MJ, Kleinman ME, Gurtner GC 2005 Adult vasculogenesis occurs through in situ recruitment, proliferation, and tubulization of circulating bone marrow-derived cells. Blood 105:10681077

52. Rehman J, Li J, Orschell CM, March KL 2003 Peripheral blood "endothelial progenitor cells" are derived from monocyte/macrophages and secrete angiogenic growth factors. Circulation 107:1164-1169
53. Gulati R, Jevremovic D, Peterson TE, Chatterjee S, Shah V, Vile RG, Simari RD 2003 Diverse origin and function of cells with endothelial phenotype obtained from adult human blood. Circ Res 93:1023-1025

54. Begley CG, Green AR 1999 The SCL gene: from case report to critical hematopoietic regulator. Blood 93:2760-2770

55. Drake CJ, Brandt SJ, Trusk TC, Little CD 1997 TAL1/SCL is expressed in endothelial progenitor cells/angioblasts and defines a dorsal-to-ventral gradient of vasculogenesis. Dev Biol 192:17-30

56. Lampugnani MG, Corada M, Caveda L, Breviario F, Ayalon O, Geiger B, Dejana E 1995 The molecular organization of endothelial cell to cell junctions: differential association of plakoglobin, beta-catenin, and alpha-catenin with vascular endothelial cadherin (VE-cadherin). J Cell Biol 129:203-217

57. Gory S, Vernet M, Laurent M, Dejana E, Dalmon J, Huber P 1999 The vascular endothelial-cadherin promoter directs endothelial-specific expression in transgenic mice. Blood 93:184-192

58. Hisatsune H, Matsumura K, Ogawa M, Uemura A, Kondo N, Yamashita JK, Katsuta H, Nishikawa S, Chiba T, Nishikawa S 2005 High level of endothelial cell-specific gene expression by a combination of the $5^{\prime}$ flanking region and the $5^{\prime}$ half of the first intron of the VE-cadherin gene. Blood 105:4657-4663

59. Prandini MH, Dreher I, Bouillot S, Benkerri S, Moll T, Huber P 2005 The human VE-cadherin promoter is subjected to organ-specific regulation and is activated in tumour angiogenesis. Oncogene 24:2992-3001

60. Alva JA, Zovein AC, Monvoisin A, Murphy T, Salazaar A, Harvey N, Carmeliet P, Iruela-Arispe ML 2006 VE-Cadherin Cre recombinase transgenic mouse: a tool for lineage analysis and gene deletion in endothelial cells. Dev Dyn, in press.

61. Soriano P 1999 Generalized lacZ expression with the ROSA26 Cre reporter strain Nat Genet. 21:70-71

62. Jiang S, Walker L, Afentoulis M, Anderson DA, Jauron-Mills L, Corless CL, Fleming WH 2004 Transplanted human bone marrow contributes to vascular endothelium. Proc Natl Acad Sci U S A 101:16891-16896

63. Caplice NM, Bunch TJ, Stalboerger PG, Wang S, Simper D, Miller DV, Russell SJ, Litzow MR, Edwards WD 2003 Smooth muscle cells in human coronary atherosclerosis can originate from cells administered at marrow transplantation. Proc Natl Acad Sci U S A 100:4754-4759

64. Quaini F, Urbanek K, Beltrami AP, Finato N, Beltrami CA, Nadal-Ginard B, Kajstura J, Leri A, Anversa P 2002 Chimerism of the transplanted heart. N Engl J Med 346:5-15

65. Hove WR, van Hoek B, Bajema IM, Ringers J, van Krieken JH, Lagaaij EL 2003 Extensive chimerism in liver transplants: vascular endothelium, bile duct epithelium, and hepatocytes. Liver Transpl 9:552-556

66. Hur J, Yoon CH, Kim HS, Choi JH, Kang HJ, Hwang KK, Oh BH, Lee MM, Park YB 2004 Characterization of two types of endothelial progenitor cells and their different contributions to neovasculogenesis. Arterioscler Thromb Vasc Biol 24:288-293

67. Ferrari N, Glod J, Lee J, Kobiler D, Fine HA 2003 Bone marrow-derived, endothelial progenitor-like cells as angiogenesis-selective gene-targeting vectors. Gene Ther 10:647-656

68. Jevremovic D, Gulati R, Hennig I, Diaz RM, Cole C, Kleppe L, Cosset FL, Simari RD, Vile RG 2004 Use of blood outgrowth endothelial cells as virus-producing vectors for gene delivery to tumors. Am J Physiol Heart Circ Physiol 287:H494-500

69. Wei J, Blum S, Unger M, Jarmy G, Lamparter M, Geishauser A, Vlastos GA, Chan G, Fischer KD, Rattat D, Debatin KM, Hatzopoulos AK, Beltinger C 2004 Embryonic endothelial progenitor cells armed with a suicide gene target hypoxic lung metastases after intravenous delivery. Cancer Cell 5:477-488

70. Kaushal S, Amiel GE, Guleserian KJ, Shapira OM, Perry T, Sutherland FW, Rabkin E, Moran AM, Schoen FJ, Atala A, Soker S, Bischoff J, Mayer JE 2001 Functional small-diameter neovessels created using endothelial progenitor cells expanded ex vivo. Nat Med 7:1035-1040

71. Ingram DA, Caplice NM, Yoder MC 2005 Unresolved questions, changing definitions, and novel paradigms for defining endothelial progenitor cells. Blood 106:1525-1531

72. Koizumi K, Tsutsumi Y, Kamada H, Yoshioka Y, Watanabe M, Yamamoto $\mathrm{Y}$, Okamoto T, Mukai Y, Nakagawa S, Tani Y, Mayumi T 2003 Incorporation of adult organ-derived endothelial cells into tumor blood vessel. Biochem Biophys Res Commun 306:219-224

73. Ingram DA, Mead LE, Moore DB, Woodard W, Fenoglio A, Yoder MC 2005 Vessel wall-derived endothelial cells rapidly proliferate because they contain a complete hierarchy of endothelial progenitor cells. Blood 105:2783-2786

74. Salven P, Mustjoki S, Alitalo R, Alitalo K, Rafii S 2003 VEGFR-3 and CD133 identify a population of $\mathrm{CD} 34+$ lymphatic/vascular endothelial precursor cells Blood 101:168-172

75. Conejo-Garcia JR, Benencia F, Courreges MC, Kang E, Mohamed-Hadley A, Buckanovich RJ, Holtz DO, Jenkins A, Na H, Zhang L, Wagner DS, Katsaros D, Caroll R, Coukos G 2004 Tumor-infiltrating dendritic cell precursors recruited by a beta-defensin contribute to vasculogenesis under the influence of Vegf-A. Nat Med 10:950-958

76. Rajantie I, Ilmonen M, Alminaite A, Ozerdem U, Alitalo K, Salven P 2004 Adult bone marrow-derived cells recruited during angiogenesis comprise precursors for periendothelial vascular mural cells. Blood 104:2084-2086

77. Armulik A, Abramsson A, Betsholtz C 2005 Endothelial/pericyte interactions. Circ Res 97:512-523 